\title{
Elucidating the Antimycobacterial Mechanism of Action of Ciprofloxacin Using Metabolomics
}

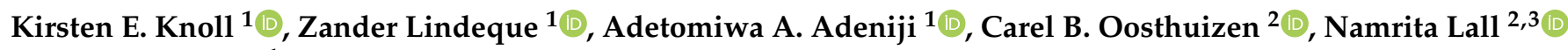 \\ and Du Toit Loots ${ }^{1, *}$ \\ 1 Department of Human Metabolomics, North-West University, Private Bag x6001, Box 269, \\ Potchefstroom 2531, South Africa; kirsten.e.knoll@gmail.com (K.E.K.); zander.lindeque@nwu.ac.za (Z.L.); \\ adenijiadetomiwa@gmail.com (A.A.A.) \\ 2 Department of Plant and Soil Sciences, Faculty of Natural and Agricultural Sciences, University of Pretoria, \\ Pretoria 0002, South Africa; carel.oosthuizen@uct.ac.za (C.B.O.); namrita.lall@up.ac.za (N.L.) \\ 3 School of Natural Resources, University of Missouri, Columbia, MO 65211, USA \\ * Correspondence: dutoit.loots@nwu.ac.za; Tel.: +27-(0)18-299-1818
}

Citation: Knoll, K.E.; Lindeque, Z.; Adeniji, A.A.; Oosthuizen, C.B.; Lall, N.; Loots, D.T. Elucidating the Antimycobacterial Mechanism of Action of Ciprofloxacin Using Metabolomics. Microorganisms 2021, 9 , 1158. https://doi.org/10.3390/ microorganisms 9061158

Academic Editor: Sangryeol Ryu

Received: 15 April 2021

Accepted: 18 May 2021

Published: 28 May 2021

Publisher's Note: MDPI stays neutral with regard to jurisdictional claims in published maps and institutional affiliations.

\begin{abstract}
In the interest of developing more effective and safer anti-tuberculosis drugs, we used a GCxGC-TOF-MS metabolomics research approach to investigate and compare the metabolic profiles of $M t b$ in the presence and absence of ciprofloxacin. The metabolites that best describe the differences between the compared groups were identified as markers characterizing the changes induced by ciprofloxacin. Malic acid was ranked as the most significantly altered metabolite marker induced by ciprofloxacin, indicative of an inhibition of the tricarboxylic acid (TCA) and glyoxylate cycle of $M t b$. The altered fatty acid, myo-inositol, and triacylglycerol metabolism seen in this group supports previous observations of ciprofloxacin action on the $M t b$ cell wall. Furthermore, the altered pentose phosphate intermediates, glycerol metabolism markers, glucose accumulation, as well as the reduction in the glucogenic amino acids specifically, indicate a flux toward DNA (as well as cell wall) repair, also supporting previous findings of DNA damage caused by ciprofloxacin. This study further provides insights useful for designing network whole-system strategies for the identification of possible modes of action of various drugs and possibly adaptations by $M t b$ resulting in resistance.
\end{abstract}

Keywords: fluoroquinolones; ciprofloxacin; untargeted metabolomics; Mycobacterium tuberculosis; tuberculosis; GCxGC-TOFMS

\section{Introduction}

Tuberculosis (TB), caused by Mycobacterium tuberculosis $(M t b)$, remains one of the leading causes of death globally from a single infectious agent [1], resulting in a mortality rate of 1.5 million and an infection rate of about 10 million annually [2]. Furthermore, the prevalence of drug resistant TB is also increasing, primarily due to poor adherence to the drug regimen in patients [3], as a result of the many side effects experienced by patients being treated with first-line anti TB medication, accompanied by the long treatment duration required [4,5]. Further contributing factors to developing drug resistant TB include inaccurate diagnosis, unsupervised treatment, poor economic status [6], and a further exacerbation in 2020 by the COVID-19 pandemic [2,7]. Currently, the WHO's approved first-line therapy for patients with active TB is a 6-month "directly observed treatment short-course" (DOTS) regimen consisting of isoniazid (INH), ethambutol (EMB), pyrazinamide (PZA), and rifampicin (RIF) [8,9]. Infection with multi-drug resistant (MDR)$\mathrm{TB}$ and extensively drug resistant (XDR)-TB requires treatment using various secondline antibiotics that are expensive, have far more side effects due to their higher toxicity, and need to be consumed for even a longer duration $[2,10]$. The only newly approved drugs for TB over the past 50 years are the second-line drugs for treating MDR-TBlinezolid, bedaquiline and delamanid-but not long after, resistance followed $[9,11,12]$. 
Considering this, there is an urgent need for well-tolerated and effective treatments for TB using drugs with novel modes of action against the infectious organism.

A suggested approach for avoiding the long drug trial phases usually required for approving new drug candidates is further investigation of already existing drugs, repurposed for use in treating TB/MDR-TB, $[13,14]$. In order for a drug to be selected for possible repurposing applications, it should preferably be affordable, easily available, and show good pharmacokinetic/pharmacodynamic properties. For these reasons, several fluoroquinolones (FQs) are being intensively investigated for use as anti-TB therapy [15]. FQs, originally used to treat urinary tract infection [16], were first shown to be effective against $M t b$ in 1984, and have since gained continuous interest for such applications [17-19]. Currently, they are among the most frequently prescribed drugs [20] and are considered the backbone of MDR-TB treatment $[10,21]$. FQs target two $M t b$ topoisomerase deoxyribonucleic acid (DNA) enzymes, DNA gyrase and topoisomerase IV [22]. The first introduces negative super helical twists in the bacterial DNA double helix and catalyzes the separation of daughter chromosomes [23], whereas the latter is responsible for the segregation into two daughter cells at the end of DNA replication [24]. Earlier generations, ciprofloxacin and levofloxacin, exhibit greater activity against Gram-negative bacteria (and some Grampositive bacteria) and target mainly DNA gyrase [25-27]. FQs inhibit DNA gyrase by binding to the enzyme and DNA, which leads to double-stranded DNA breaks [28-32].

The innate resistance mechanism of $M t b$ to many anti-TB drugs can be attributed to its complex cell wall [33]; however, the specific, highly lipophilic characteristics of FQs [34] provide great permeability over this [35]. These antibiotics chelate with $\mathrm{Mg}^{2+}$ cations and electrostatically interact with membrane phosphodiesters, subsequently traversing the $M t b$ cell wall [36]. FQs are not exempt from resistance, however, of which the best described are mutations in genes $g y r A$ and $g y r B$, encoding subunit GyrA and GyrB of DNA gyrase [37-39]. Furthermore, several resistance-forming proteins have also been identified, including the efflux pumps, LfrA [40,41], and MmpL (mycobacterial membrane protein large) [42], the target protection proteins, MfpA and MfpB (Mycobacterium fluoroquinolone resistance proteins A and B) [43,44], and the cell-survival promotor, HtrA2 (high temperature requirement A) [45]. DNA repair and mutations by the SOS regulon have also been described [18].

Although interactions between DNA gyrase and FQs have been thoroughly investigated $[22,38,46]$, little is known about their biochemical mechanisms of action against $M t b$ specifically, or $M t b$ drug resistance to these $[10,19]$. The results published thus far are somewhat contradictory. In a study by Verma et al. [47], the macromolecular composition of the M. smegmatis cell wall after sub-MIC ciprofloxacin treatment indicated a significant decrease in the total lipids, phospholipids, and sugars, suggesting ciprofloxacin-induced alterations of the cell wall. In contrast, Halouska et al. [48] indicated ciprofloxacin-induced inhibition of transcription, translation, and DNA supercoiling, without changes to the cell wall.3 While most data suggest cell death due to the inhibition of DNA replication [49], altered DNA biosynthesis could set in motion secondary events contributing to ciprofloxacin's bacteriostatic or bactericidal effects. Furthermore, it is important to remember that stronger target activity does not predict better antimycobacterial activity. This is perfectly demonstrated by ciprofloxacin dimers, which show enhanced DNA gyrase inhibition, while less effectively killing $M t b$ [50]. This is thought to be due to a stronger cleavage of FQ to the DNA-enzyme complex, which results in less single-strand DNA fragments, and subsequently prevents RecA from recognizing damaged DNA and inducing the SOS regulon [32]. The SOS response assists in killing by releasing ROS [51,52], yet simultaneously activates DNA repair and creates a dormancy state, ultimately leading to resistance. Before this SOS response can be used to advantage as a possible mode of action against $M t b$, this phenomenon, and how it connects to the mechanism of ciprofloxacin, still needs to be elucidated.

The selection of ciprofloxacin as our investigational compound was predominantly based on its safety profile. Although less potent than moxifloxacin (MIC 0.12-0.5 $\mathrm{gg} / \mathrm{mL}$ ), and levofloxacin (MIC $1 \mu \mathrm{g} / \mathrm{mL}$ ), ciprofloxacin (MIC 0.5-4.0 $\mu \mathrm{g} / \mathrm{mL}$ ) [53] has the lowest 
risk for causing serious ventricular arrhythmia, cardiovascular mortality, and hepatotoxicity $[54,55]$. Furthermore, ciprofloxacin demonstrates the highest clearance rate of all FQs [56] and is thus the preferred option for the treatment of renally impaired patients [17]. The levels of ciprofloxacin in cerebrospinal fluid can be as high as $40-90 \%$ compared to that in plasma [53], which offers further advantages for its use in the treatment of tuberculous meningitis. Adverse drug reactions (ADRs) are usually minimal (5\% or less), and the most common ADRs are usually gastrointestinal in nature (nausea, vomiting, diarrhea, and abdominal pain) $[57,58]$. Previous studies demonstrated that mitochondrial topoisomerases bear less than 30\% homology to their prokaryotic counterparts and are not inhibited [23,59], but it has been reported that ciprofloxacin does affect mitochondrial DNA synthesis [60]. The pharmacological advantages of ciprofloxacin have not gone unnoticed, as stated by the World Health Organization [61], which has included ciprofloxacin as a critically important antibiotic.

Most of the evidence brought to light thus far has been generated using genomics, transcriptomics, or proteomics [62]. Metabolomics, the latest addition to "omics" technologies, identifies the down-stream metabolites of altered pathways and therefor presents a more sensitive level of organization, from which up-stream deductions can be made $[8,63]$. We identified the metabolite markers best differentiating $M t b$ with and without ciprofloxacin, using a two-dimensional gas chromatography coupled with time-of-flight mass spectrometry (GCxGC-TOF-MS) metabolomics approach, combined with universally connected metabolic libraries and advanced statistical analysis, in order to better elucidate its mechanism of action.

\section{Materials and Methods}

\subsection{Bacterial Culture}

Antimycobacterial minimum inhibitory concentration (MIC) and sub-MIC (50\% inhibitory concentrations $\left(\mathrm{MIC}_{50}\right)$ ) of ciprofloxacin were determined via the Alamar Blue assay [64]. The cell cultures (5 individually cultured samples per group) were prepared as previously described [65], in the presence and absence of ciprofloxacin. All reagents were purchased from Sigma-Aldrich, St. Louis, MO, USA, unless otherwise stated. Briefly, Mtb H37Rv ATCC 27294 (kindly obtained from the Medical Research Council, Pretoria, Gauteng, South Africa) was cultured and maintained for 4 weeks on Lowenstein Jensen (LJ) slants. The bacterial inoculum was prepared to a McFarland standard of 1 (approximately $3 \times 10^{8}$ colony-forming units $/ \mathrm{mL}$ ) in Middlebrook $7 \mathrm{H} 9$ broth supplemented with $10 \%$ OADC (oleic acid, albumin, dextrose, catalase) (Becton, Dickinson, UK) and $2 \%$ PANTA (polymyxin B, amphotericin B, nalidixic acid, trimethoprim, and azlocillin) (Becton, Dickinson, UK). PANTA was added for the prevention of contamination with negligible impact on Mtb's growth [66]. Ciprofloxacin was dissolved in DMSO $(150 \mu \mathrm{M})$, added as a vehicle control, and diluted into Middlebrook 7H9 broth to a final concentration of $0.3 \mu \mathrm{M}$ $(0.12 \mu \mathrm{g} / \mathrm{mL})(0.2 \% \mathrm{DMSO})$. One milliliter of the prepared inoculum was added to yield a final assay volume of $5 \mathrm{~mL}$, with a bacterial test concentration of $6 \times 10^{7} \mathrm{CFU}$ per $1 \mathrm{~mL}$ of ciprofloxacin. For the untreated $M t b$ control samples, $4 \mathrm{~mL}$ of Middlebrook $7 \mathrm{H} 9$ broth $(0.2 \%$ DMSO $)$ was added to each replicate culture, followed by the addition of the bacterial inoculum as described above. The DMSO solvent was kept constant throughout the assay. After 5 days of incubation at $37^{\circ} \mathrm{C}$, the samples were centrifuged to pellet the bacteria at $4500 \mathrm{rpm}$ for $15 \mathrm{~min}$. The pellets were washed with $1 \mathrm{~mL}$ of PBS and pelleted again under the same conditions. Finally, the PBS was aspirated from the samples and the pellets were stored immediately at $-80^{\circ} \mathrm{C}$ until further testing.

\subsection{Whole Metabolome Extraction Procedure and Derivatization}

The metabolites were extracted from the samples and derivatized as previously described by Beukes, et al. [67], with slight modifications. Briefly, $8 \mathrm{mg}$ of each of the individually cultured samples were weighed out into an Eppendorf tube, followed by the addition of $50 \mu \mathrm{L}$ 3-phenylbutyric acid $\left(0.13 \mathrm{mg} / \mathrm{ml} \mathrm{H}_{2} \mathrm{O}\right)$ (Sigma-Aldrich, Lot\#536478V) as 
internal standard. One milliliter of a chloroform: methanol: water (1:3:1 ratio) solution was added, after which the Eppendorf tubes were shaken in a vibration mill at $30 \mathrm{~Hz}$ for $5 \mathrm{~min}$, with a $3 \mathrm{~mm}$ carbide tungsten bead in each. The samples were centrifuged at 12,000 rpm for $5 \mathrm{~min}$ and the supernatant was transferred to a GC glass vial. The extracts were dried under a nitrogen stream, followed by the addition of $50 \mu \mathrm{L}$ methoxamine hydrochloride (SigmaAldrich, Lot\#BCBP2843V) in pyridine (Lot\#S2BC335SV) at a concentration of $15 \mathrm{mg} / \mathrm{mL}$. The glass vials were heated at $50{ }^{\circ} \mathrm{C}$ for $90 \mathrm{~min}$. Following, methoximation, $40 \mu \mathrm{L} \mathrm{N}, \mathrm{O}-$ bis(trimethylsilyl)trifluoroacetamide with 1\% trimethylsilyl chloride (Lot\#BCBW2670) was added, and vials were heated again for $60 \mathrm{~min}$ at $50{ }^{\circ} \mathrm{C}$. Each extract was then transferred to a $0.1 \mathrm{~mL}$ vial insert in a GC sample vial and injected into GCxGC-TOF-MS.

\subsection{GCXGC-TOFMS Analysis}

A 4D Pegasus GCxGC-TOF-MS (LECO Africa (Pty) Ltd., Johannesburg, South Africa) equipped with a Gerstel Multi-Purpose Sampler (Gerstel GmbH and Co. KG, Mülheim an der Ruhr, Germany) and an Agilent 7890 gas chromatograph (Agilent, Atlanta, USA) coupled to TOF-MS (LECO Africa) were used for the analysis. The samples were analyzed in random sequence, with split-less injection. To monitor the analytical performance throughout the entire analysis, a quality control (QC) sample was analyzed at regular intervals. The processed samples were injected into Rxi-5Sil MS primary capillary column ( $28.8 \mathrm{~m} \times 0.25 \mathrm{~mm}$ internal diameter, $0.25 \mu \mathrm{m}$ film thickness, Restec), and a Rxi-17 secondary capillary column $(1.2 \mathrm{~m} \times 0.25 \mathrm{~mm}$ internal diameter, $0.25 \mu \mathrm{m}$ film thickness), for GC compound separation. The primary GC oven temperature was set at $70{ }^{\circ} \mathrm{C}$ for $2 \mathrm{~min}$, and then increased at a rate of $4{ }^{\circ} \mathrm{C} / \mathrm{min}$ to a final temperature of $300{ }^{\circ} \mathrm{C}$, at which it was maintained for an additional $2 \mathrm{~min}$. The secondary oven was set at $85^{\circ} \mathrm{C}$ for $2 \mathrm{~min}$, increased at $4.5^{\circ} \mathrm{C} / \mathrm{min}$, to a final temperature of $300^{\circ} \mathrm{C}$, at which it was maintained for $4.5 \mathrm{~min}$. Helium, set to a column flow rate of $1 \mathrm{~mL} / \mathrm{min}$, was used as a carrier gas, and held at a constant temperature of $270{ }^{\circ} \mathrm{C}$. Mass spectrometric data acquisition was carried out at $-70 \mathrm{eV}$, with a solution delay of $350 \mathrm{sec}$, and a mass range of $50-800 \mathrm{~m} / \mathrm{z}$ was scanned with a rate of 200 spectra/sec.

\subsection{Data Processing, Clean-Up, and Statistics}

ChromaTof software (version 4.32) was used for mass spectral deconvolution (at a signal to noise ratio of 20), peak alignment, and peak identification on the obtained mass spectra. Metabolites were identified by comparing their mass fragment patterns to those of compounds in commercially available databases containing previously injected standards. For normalization and assessment of data quality, the data were pretreated using a standardized metabolomics data clean-up procedure [67]. Each detected compound was normalized using MS total useful signal (TUS), which is based on a factor calculated from the sum of all metabolites identified in all samples, and by calculating the relative concentration of each by using the internal standard. All missing/zero values were replaced by a value calculated as $20 \%$ of the minimum detection limit of the entire dataset, as these are most likely present in sub-minimum concentrations rather than being completely absent [68]. An $80 \%$ data filter was then applied to eliminate compounds with more than $80 \%$ zero values within both groups [69]. To provide a balanced representation of all metabolites, log transformation and auto-scaling (mean-centered and divided by the standard deviation of each variable) were applied. This prevents compounds with minor concentrations from being overlooked due to the domination of compounds with higher concentrations [70]. Making use of MetaboAnalyst (Version 5.0) [71], multivariate statistical methods in the form of unsupervised principal component analysis (PCA) and supervised partial least squares-discriminant analysis (PLS-DA) were applied [72]. Subsequently, uni-variate analysis was performed by calculating t-test and effect size values [73].

Relationships between the selected metabolites were mapped using the KEGG, Meta$\mathrm{Cyc}$, and BioCyc databases, in addition to intensive research of the previously published literature on the topic. 


\section{Results}

\subsection{Data Overview}

When visualizing the analytical technique's repeatability graphically (Figure 1), approximately $86 \%$ of all the compounds identified $(n=260)$ had a coefficient of variation (CV) value under $50 \%$, while $70 \%$ had CV values under $20 \%$. The analytical technique used during this analysis thus proved to be highly repeatable and can could be trusted to provide reliable results. PCA was initially used to obtain an overview of the natural grouping of metabolic data (Figure 2). The total variance between the groups, described by the first two principal components (PCs), was $57.1 \%$, of which PC1 and PC2 accounted for $32.1 \%$ and $25 \%$, respectively. The PCA scores plot of the metabolite data analyzed by GCxGC-TOF-MS shows clear clustering between $M t b$ in the presence and absence of ciprofloxacin, as represented in Figure 2.

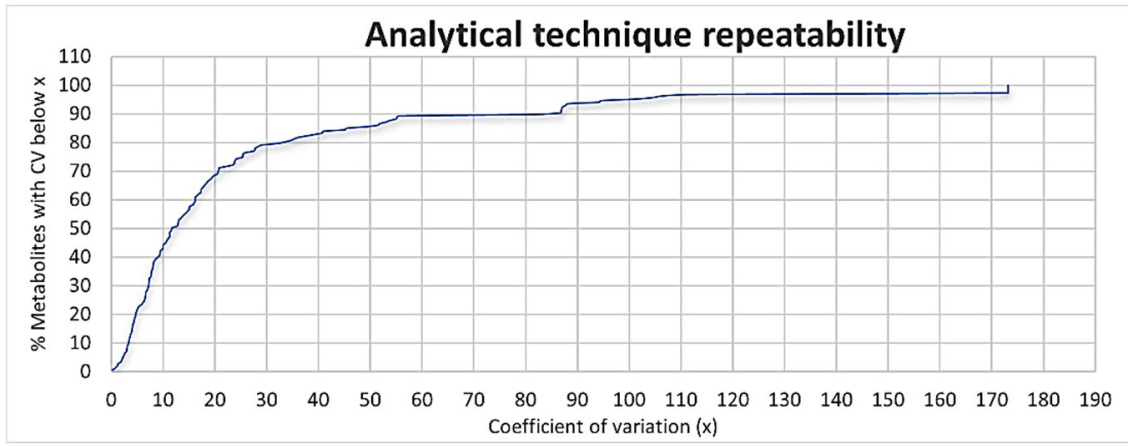

Figure 1. Distribution of the coefficients of variation values for technical repeatability.

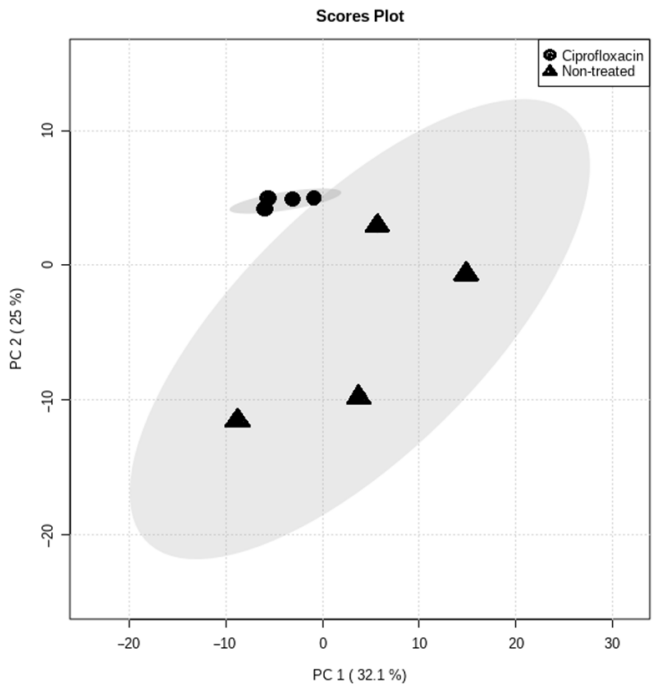

Figure 2. PCA scores plot obtained from GCxGC-TOFMS whole metabolome analysis of $M t b$ samples in the presence and absence of ciprofloxacin. The variances accounted for are indicated in parentheses.

\subsection{Marker Selection}

The metabolite markers $(n=26)$ best describing the differences between the ciprofloxacin and control samples were selected based on compliance with the following criteria: a PLSDA VIP value $>1$ [74], a $t$-test $p$-value $<0.05$ [75], or an effect size $>0.8$ [76] (Figure 3).

The selected metabolite markers are listed according to their PLS-DA VIP values in Table 1, along with their respective average concentrations and univariate test outcomes. Of the total, $61.5 \%(16 / 26)$ of the markers were elevated; most of these were fatty acids. The most differentiating marker was malic acid, with an exceptionally high d-value of 6.621 and low $p$-value of $>0.0001$. 


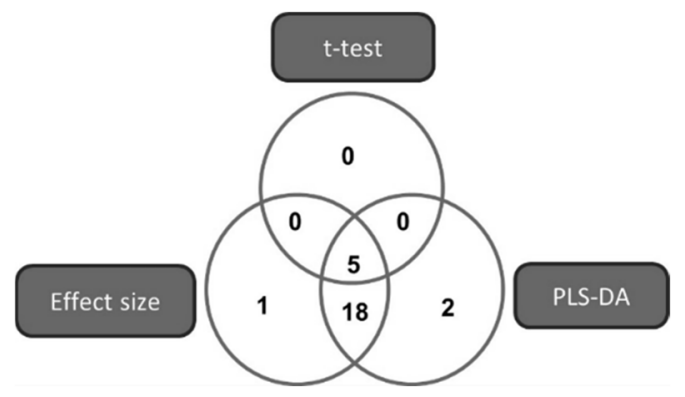

Figure 3. Venn diagram illustrating the multi-statistical approach for selecting the metabolites that best describe the variation detected in the metabolome of $M t b$ cultured with and without ciprofloxacin.

Table 1. Metabolite markers best describing the variance between the individually cultured $M t b$ samples in the absence ( $M t b$ controls) and presence of ciprofloxacin.

\begin{tabular}{|c|c|c|c|c|c|c|}
\hline \multirow[t]{2}{*}{$\begin{array}{l}\text { Metabolite Name } \\
\text { (ChEBI ID) }\end{array}$} & \multicolumn{2}{|c|}{$\begin{array}{c}\text { Average Concentration } \\
\text { (mg/g Cell Mass) } \\
\text { (Standard Deviation) }\end{array}$} & \multirow[t]{2}{*}{$\begin{array}{c}t \text {-Test } \\
(p \text {-Value })\end{array}$} & \multirow[t]{2}{*}{$\begin{array}{l}\text { Effect Size } \\
\text { (d-Value) }\end{array}$} & \multirow[t]{2}{*}{ PLS-DA (VIP) } & \multirow[t]{2}{*}{$\begin{array}{l}\text { Fold Change } \\
\qquad\left(\log _{2}\right)\end{array}$} \\
\hline & $\begin{array}{l}\text { Mtb with } \\
\text { Ciprofloxacin }\end{array}$ & $M t b$ Controls & & & & \\
\hline Malic acid (6650) & $0.033(0.002)$ & $0.054(0.004)$ & 0.000 & 6.621 & 2.012 & -0.39 \\
\hline Aspartic acid (17053) & $0.007(0.001)$ & $0.013(0.004)$ & 0.008 & 2.236 & 1.732 & -0.46 \\
\hline Glycerol (17754) & $0.497(0.033)$ & $0.633(0.031)$ & 0.013 & 1.932 & 1.678 & -0.21 \\
\hline 5-Oxoproline (17203) & $0.069(0.014)$ & $0.099(0.020)$ & 0.014 & 1.962 & 1.665 & -0.30 \\
\hline Xylofuranose (46432) & $0.075(0.037)$ & $0.034(0.008)$ & 0.037 & 1.376 & 1.511 & 1.21 \\
\hline Myo-inositol-1-phosphate (18297) & $0.004(0.001)$ & $0.003(0.001)$ & 0.051 & 1.637 & 1.445 & 0.33 \\
\hline 9-Hexadecenoic acid (28716) & $0.005(0.000)$ & $0.004(0.001)$ & 0.091 & 1.329 & 1.299 & 0.25 \\
\hline Nonadecanoic acid & $0.067(0.011)$ & $0.055(0.008)$ & 0.094 & 1.151 & 1.292 & 0.22 \\
\hline Heptadecanoic acid (32365) & $0.015(0.003)$ & $0.011(0.002)$ & 0.095 & 1.355 & 1.288 & 0.36 \\
\hline Octadecanoic acid (28842) & $0.582(0.164)$ & $0.371(0.141)$ & 0.096 & 1.241 & 1.287 & 0.57 \\
\hline Valine (16414) & $0.017(0.004)$ & $0.022(0.005)$ & 0.106 & 1.117 & 1.255 & -0.23 \\
\hline$\beta$-Aminoisobutanoic acid (33094) & $0.011(0.002)$ & $0.014(0.004)$ & 0.121 & 1.256 & 1.216 & -0.21 \\
\hline Glutamic acid (16015) & $0.010(0.001)$ & $0.015(0.006)$ & 0.124 & 0.960 & 1.209 & -0.33 \\
\hline Hexadecanoic acid (15756) & $0.575(0.051)$ & $0.480(0.077)$ & 0.128 & 0.969 & 1.198 & 0.20 \\
\hline 9-Octadecenoic acid (36021) & $0.679(0.060)$ & $0.600(0.041)$ & 0.132 & 1.089 & 1.187 & 0.13 \\
\hline Tetradecanoic acid (28875) & $0.089(0.010)$ & $0.071(0.017)$ & 0.141 & 0.934 & 1.167 & 0.25 \\
\hline Eicosanoic acid (28822) & $0.005(0.001)$ & $0.004(0.000)$ & 0.146 & 0.991 & 1.154 & 0.25 \\
\hline Glucose (17234) & $0.045(0.006)$ & $0.037(0.005)$ & 0.152 & 0.934 & 1.140 & 0.22 \\
\hline Urea (16199) & $0.005(0.002)$ & $0.002(0.002)$ & 0.171 & 0.816 & 1.099 & 1.50 \\
\hline N-Acetyl-L-Lysine (64859) & $0.002(0.001)$ & $0.004(0.003)$ & 0.175 & 0.884 & 1.090 & -0.50 \\
\hline 2-Monopalmitin (75455) & $0.011(0.002)$ & $0.009(0.001)$ & 0.175 & 0.907 & 1.089 & 0.22 \\
\hline 1-Monomyristin (75562) & 0.007 (0.003) & $0.005(0.001)$ & 0.175 & 0.882 & 1.089 & 0.40 \\
\hline Pentadecanoic acid (42504) & $0.005(0.001)$ & $0.004(0.001)$ & 0.181 & 1.021 & 1.077 & 0.25 \\
\hline Glycerol 3-phosphate (15978) & $0.005(0.001)$ & $0.007(0.002)$ & 0.186 & 0.908 & 1.067 & -0.29 \\
\hline 1-Monoheptadecanoin (144339) & $0.010(0.002)$ & $0.007(0.001)$ & 0.186 & 0.947 & 1.066 & 0.43 \\
\hline Erythritol (17113) & $0.021(0.002)$ & $0.023(0.001)$ & 0.202 & 0.856 & 1.034 & -0.09 \\
\hline
\end{tabular}

\section{Discussion}

In this study, we identified a number of significantly altered metabolites induced by the administration of ciprofloxacin to $M t b$ culture, which when interpreted, in the light of known metabolism and previous ciprofloxacin findings, better elucidate its mechanisms of action against $M t b$, as shown in Figure 4. The most prominently altered pathways included gluconeogenesis, fatty acid metabolism, amino acid metabolism, the pentose phosphate pathway (PPP), and the urea cycle.

Of note were the elevated levels of various even- and odd-chain saturated fatty acids of between 14 to 20 carbons (C14:0-C20:0) in length, in the Mtb treated with ciprofloxacin. This was also true for two $\Delta^{9}$-unsaturated fatty acids; 9-hexadecenoic $\left(\Delta^{9} \mathrm{C} 16: 1\right)$, and 9octadecenoic $\left(\Delta^{9} \mathrm{C} 18: 1\right)$ acids. These indicate a strongly upregulated synthesis toward cell wall repair, supporting previous evidence associating ciprofloxacin with cell wall damage [47]. Simplified, lying outside of the cytoplasmic membrane, a peptidoglycan (PG) layer is covalently attached to arabinogalactan (AG), which itself attaches to mycolic acids (MA) to form the MA-AG-PG complex (MAPc) [77,78]. Interspersed within the MAPc, are the glycerolipids, phosphatidyl myo-inositol mannosides (PIM) and lipoarabinoman- 
nans (LAM) [79]. PIM is a crucial part of the membrane structure and serves as a precursor of LAM [80]. The saturated fatty acid markers in this study are produced by fatty acid synthase type I (FAS I). FAS I generates 16 to 26 carbon length fatty acyl-coenzyme As (CoA) [81], which are fed into FAS II for elongation. FAS I and FAS II provide acyl groups for the synthesis of all cell envelope components, except for AG [82,83]. $\Delta^{9} \mathrm{C} 16: 1$ and $\Delta^{9} \mathrm{C} 18: 1$ and their precursors, hexadecanoic (C16:0) and octadecanoic (C18:0) acid, respectively, are considered major fatty acids of glycerolipids and mycolic acids [84-86]. $\Delta^{9} \mathrm{C} 16: 1$ and $\Delta^{9} \mathrm{C} 18: 1$ are reduced from $\mathrm{C} 16: 0$ and $\mathrm{C} 18: 0$, in the presence of $\mathrm{Fe}^{2+}$, a flavin, NADPH, and $\mathrm{O}_{2}[87,88]$. Interestingly, some $m m p L$ genes, encoding fatty acid transporter protein MmpL have been shown to be repressed when their transcriptional regulator proteins bind to C:16 fatty acids and monoacylglycerols (MAG) $[89,90]$. Even so, further research is needed to establish possible activity of different fatty acids on different $\mathrm{MmpL}$ regulator proteins. It is, however, important to note that the damage that ciprofloxacin administration induces to the cell wall may be direct, but is most likely indirect, by inhibition of other energy-producing mechanisms or simply by induction of the SOS response in $M t b$, shifting energy production away from glucose toward the preferential use of fatty acids [91]; hence, less of these fatty acids are now available to cell wall synthesis. Increased FA synthesis or the accumulation of cell wall components has also been identified in $M t b$ treated with EMB, INH, PZA, RIF, and pretomanid [92-96].

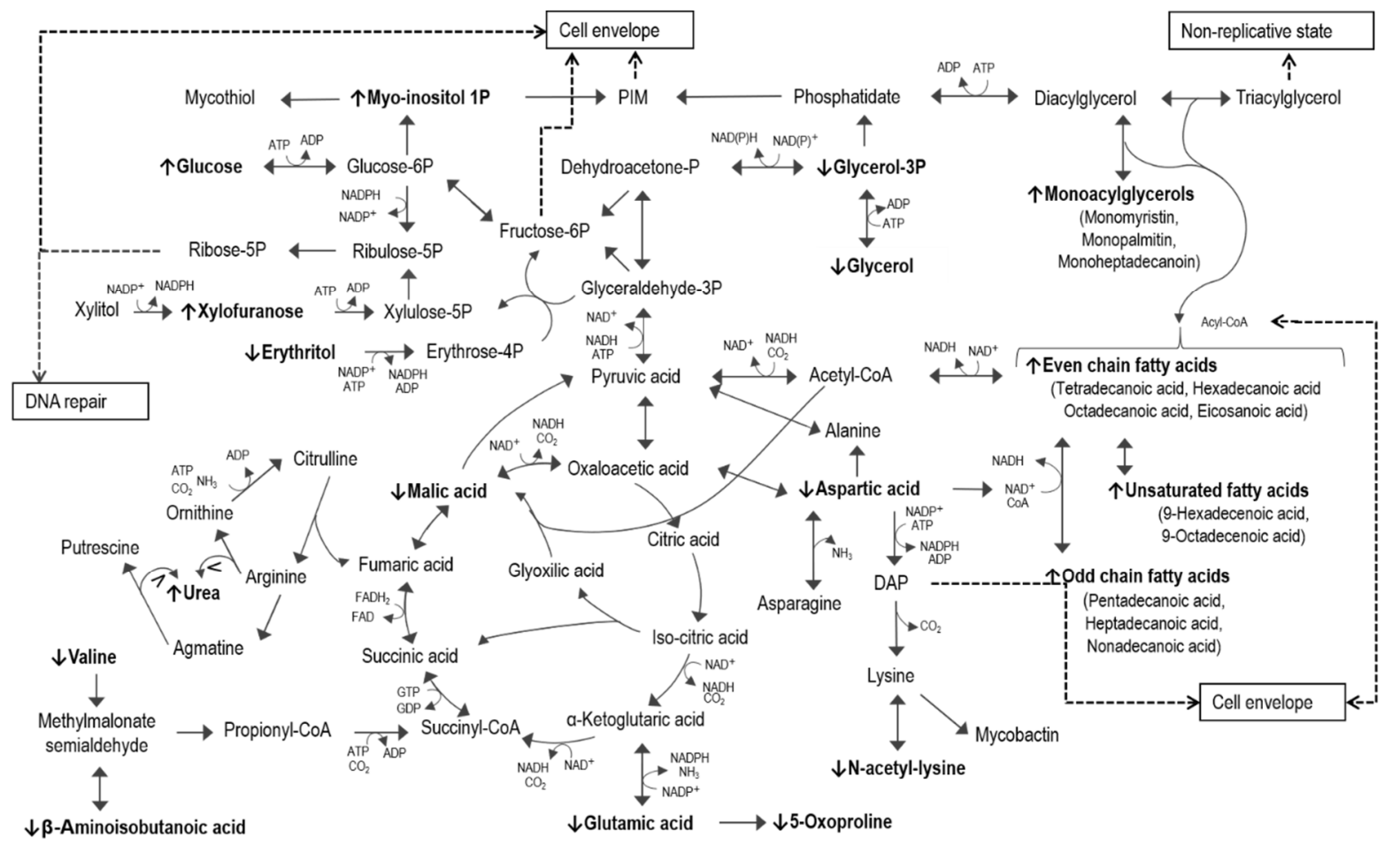

Figure 4. Metabolomic pathway map of $M t b$ treated with ciprofloxacin. The metabolite markers best describing the variation in the metabolome compared to those of untreated $M t b$ are represented in bold text with up or down arrows indicating elevated or reduced concentrations, respectively.

The dramatically elevated synthesis of intracellular fatty acids would be expected to consume a considerable amount of carbon, which can be supplied from various sources [91]. However, as will be explained, glucose and glycerol seem to be the major suppliers for such, and for the various components required for DNA repair. This is supported by previous findings indicating ROS, produced during the FQ-induced SOS-response, causes oxidative stress, which in turn activates utilization of triacylglycerol (TAG) and cell wall lipids for energy [97-99], as is generally the case during the non-replicative phase of $M t b[100,101]$. These results are also supported by previous findings showing reduced concentrations of 
phospholipids and mycolic acids in the cell wall macromolecules of sub-MIC ciprofloxacintreated M. smegmatis [47], because these are now being preferentially used for energy production, with glucose supplying the necessary carbon substrates for the continued synthesis of these much-needed fatty acids, which are now preferentially used for energy production.

A shift in energy supply to $\beta$-oxidation of fatty acids, as opposed to the TCA cycle, reserves $\mathrm{NAD}^{+}$, in addition to $\mathrm{CO}_{2}$, for de novo synthesis of nucleotides (for DNA repair and fatty acids). NADH and NADPH released during fatty acid metabolism fuel the upregulated non-oxidative PPP and glycerolipid metabolic pathway. In this study, the downregulated TCA cycle was indicated by a reduction in malic acid and aspartic acid, which according to the uni- and multivariate statistics, were ranked as the two most important metabolite markers altered by ciprofloxacin (Table 1). Aspartic acid is considered a validated reporter of oxaloacetate (OAA) [102], and together with malic acid, supports TCA cycle inhibition. Although oxidative stress is normally associated with an increase in glyoxylate shunt activity, in this study the glyoxylate shunt was clearly downregulated. This indicates a greater need of carbon flux through gluconeogenesis toward the PPP and glucose, for subsequent fatty acid and nucleotide synthesis [103,104]. Reduced aspartic acid concentrations were also previously found in a study investigating phenotypic antibacterial persistence in $M t b$ [105]. These results support the SOS response-induced decrease in oxidative phosphorylation and increase in energy reserves for DNA repair in response to FQs [32,102]. It is noteworthy to mention that the ATPase activity of DNA gyrase (29), shows reduced adenosine triphosphate (ATP) conversion in the presence of ciprofloxacin [106], which most likely is for the purpose of reserving ATP for other energy consuming pathways, such as gluconeogenesis and DNA repair [107].

Various PPP intermediates that contribute to DNA and cell wall synthesis were detected to be altered in the ciprofloxacin-treated $M t b,[99,108,109]$. Under normal circumstances, erythrose-4-phosphate and glyceraldehyde-3-phosphate produce xylulose5-phosphate (xylulose-5P) and fructose-6-phosphate (fructose-6P) [91]. The latter is converted to glucose-6-phosphate, for subsequent PIM synthesis, via the myo-inositol pathway [110], and to glucose-N-acyl 6-phosphate (GlcN6P), for subsequent PG synthesis [111]. Xylose-5P is the precursor of ribose-5-phosphate (ribose-5P), which, in the presence of ATP, is converted to 5-phosphoribosyl-1-pyrophosphate (pRpp) [103,112]. PRpp is the branch point intermediate of decaprenyl-phospho-arabinofuranose (DPA) [113], the only donor of arabinose to AG and LAM [104,114] and nucleotide synthesis. In this investigation, the upregulated non-oxidative PPP in the ciprofloxacin-treated $M t b$ was supported by the elevated concentrations of xylofuranose and reduced erythritol (Figure 4). Furthermore, it is well known that PPP metabolism is fueled by glucose and the glucogenic amino acids valine, aspartic acid, and glutamic acid [115], all of which were specifically and significantly reduced in the ciprofloxacin-treated $M t b$, in addition to their degradation products $\beta$-aminoisobutanoic acid [116], 5-oxoproline [117], and N-acetyl-lysine [118], respectively (Figure 4). Furthermore, the reduced levels of glutamic acid and aspartic acid in our investigation supported an oxidative state in the ciprofloxacin-treated group [119]. The above-mentioned amino acids also serve as precursors of cell wall related intermediates. Alanine derived from aspartic acid combines with valine to produce CoA, which is used for converting fatty acids into cell wall lipids [120-122]. Valine also serves as a precursor of propionyl-CoA [116,123] and is used for the elongation of odd-chain fatty acids [124]. Aspartic acid additionally is the precursor of $\mathrm{NAD}^{+}, 2,6$-diaminopimelate (DAP) $[125,126]$, and S-adenosyl methionine (SAM) [127]. Considering this, $\mathrm{NAD}^{+}$is subsequently an important cofactor for FAS I [128], and SAM is required for the methylation of cell-wall fatty acids [129]. Furthermore, the aforementioned DAP, along with alanine and glutamic acid, serve as substrates for PG [130]. Lastly, the observed flux through aspartic acid can be supported by the elevated levels of urea in $M t b$ treated with ciprofloxacin [131], and considering that aspartic acid is one of the top three metabolite markers identified (Table 1), it is possibly utilized, contributing to many of the cell-envelope changes observed. 
The FQ-induced SOS response is known to cause cell growth arrest [132], and in this study, inhibited cell growth is evident by the increased TAG metabolism and reduced TCA activity, in addition to the inhibited protein synthesis observed in the ciprofloxacin-treated $M t b$. Protein synthesis requires ATP-dependent activation of glutamate and aspartate, followed by amination by ammonia, to form aminoacyl-tRNA [115]. However, in this study, urea was found to be elevated in $M t b$ treated with ciprofloxacin, indicating accumulation of ammonia and reduced recycling of nitrogen via glutamine and proline metabolism. This, in addition to a decreased degradation of urea by urease, also linked to the $M t b$ stress response [133], retains ammonia from protein synthesis [134]. Inhibited protein formation has also been suggested in a proteomics study of $M t b$ treated with ciprofloxacin [135], as well as a metabolomics study of $M$. smegmatis treated with ciprofloxacin [48]. Disruption of protein synthesis has also been reported in studies investigating the response of $M t b$ to pretomanid, streptomycin, EMB, RIF, PZA, and INH [95,136-138]. The inhibited protein synthesis observed would in turn disrupt the functionality of membrane proteins, subsequently inhibiting nutrient uptake as well as fatty acid transport to the cell wall [42]. Additionally, urea acts as an osmolyte, preventing dehydration or water loss as a result of the seemingly damaged cell wall [139]. Increased urea could also be indicative of polyamine synthesis (Figure 4) [140]. Polyamines, such as putrescine, have been reported to reduce accumulation of trans-membrane proteins [141] and contribute to the phenotypic drug resistance to FQs [142].

Observed changes to the monoacylglycerols (MAG) 1-monomyristin, 2-monopalmitin, and 1-monoheptadecanoin are indicative of cell envelope changes via the glycerolipid and triacylglycerol (TAG) pathways. TAG in the cell wall [143] can be metabolized during the stress-induced transition to the non-replicated phase [144] and during infection [145]. $M t b^{\prime}$ s adaptation during these circumstances involves the use of lipids as main energy reserves, as previously mentioned [146]. During the deacetylation of TAG to diacylglycerol (DAG), and from DAG to MAG, acyl-CoAs are released, which are either directed toward glycerolipid synthesis (Figure 4) or energy production [147,148]. Glycerolipid and TAG metabolism share an important intermediate at the branch point, 1,2-diacyl-sn-glycerol 3-phosphate, commonly known as phosphatidate (PA) (Figure 4) [149]. PA is synthesized via two pathways: 1) the phosphorylation of DAG by DAG kinase [150] or 2) the acylation of glycerol-3-phosphate (glycerol-3P) by glycerol phosphate and acyl glycerol phosphate acyltransferase [151]. In this study, the concentrations of glycerol-3-phosphate and its precursor glycerol were decreased, supporting a MAG metabolic flux toward TAG and PIM in the ciprofloxacin-treated $M t b$ group. Glycerol-3P appears to recycle the transport of membrane lipids [152] and can thus be expected to be the rate-limiting step, which would explain the accumulation of the fatty acids and the accompanying reduction in glycerol levels. The synthesis of glycerolipids also requires myo-inositol, which is produced via glucose-6-phosphate (glucose-6P) [153]. Firstly, myo-inositol 3-phosphate synthase converts glucose-6P into myo-inositol 3-phosphate, which in turn is dephosphorylated by several myo-inositol monophosphates to produce myo-inositol [84]. The elevated levels of myo-inositol monophosphates in the ciprofloxacin-treated $M t b$ hence further support the aforementioned flux toward glycerolipids [154]. Furthermore, myo-inositol-1-phosphate is converted by a glycosyltransferase, mycothiol (Msh). Mycothiol is also considered an important antioxidant required for balancing the cytosolic $\mathrm{NAD}^{+} / \mathrm{NADH}$ ratio [155]. In addition to the abovementioned inhibition of protein synthesis and enhanced fatty acid synthesis, altered energy metabolism has also consistently been identified in response to the first-line drugs INH [156], EMB [157], PZA [158], and RIF [159], supporting these results. In summary, the mycobacterial cell wall metabolism is visibly linked to the SOS response, which has frequently been proposed to cause resistance toward ciprofloxacin and challenge the otherwise impressive bactericidal activity of this drug [18,160-162]. 


\section{Conclusions}

In this study, we investigated the metabolic changes to $M t b$ induced by sub-MIC of ciprofloxacin, in order to better understand its mechanism of action and the resultant adaptations of $M t b$. Previous studies have identified alterations in transcription, translation, and cell wall synthesis as part of the mechanism of action of ciprofloxacin against $M t b$ (51, $52,135)$. Our metabolomics study identified metabolite markers that support previous results, as indicated by the drastic accumulation of metabolites associated with cell wall and DNA repair. Moreover, many of these markers indicate an SOS-induced shift to the nonreplicative phase, which is a key mechanism determining $M t b$ persistence and tolerance to various anti-TB drugs. This study not only gives a better understanding of ciprofloxacin's mode of action but provides helpful insight for further investigation of antibiotic-induced resistance by $M t b$, and also perhaps the use of ciprofloxacin in combination with existing anti-TB drugs.

Author Contributions: D.T.L. and A.A.A. contributed to the conceptualization, project administration, supervision, and data interpretation. Z.L. contributed to the analysis, data curation and validation. C.B.O. and N.L. contributed to the resources. K.E.K. contributed to the project administration, analysis, data curation and validation. All authors contributed to the writing, review, and editing of the manuscript. All authors have read and agreed to the published version of the manuscript.

Funding: This research did not receive any specific grant from funding agencies in the public, commercial, or non-profit sectors.

Institutional Review Board Statement: Not applicable.

Informed Consent Statement: Not applicable.

Data Availability Statement: Not applicable.

Conflicts of Interest: The authors declare no conflict of interest.

\section{References}

1. MacNeil, A.; Glaziou, P.; Sismanidis, C.; Maloney, S.; Floyd, K. Global epidemiology of tuberculosis and progress toward achieving global targets-2017. Morb. Mortal. Wkly. Rep. 2019, 68, 263. [CrossRef]

2. Harding, E. WHO global progress report on tuberculosis elimination. Lancet Respir. Med. 2020, 8, 19. [CrossRef]

3. Vernon, A.; Fielding, K.; Savic, R.; Dodd, L.; Nahid, P. The importance of adherence in tuberculosis treatment clinical trials and its relevance in explanatory and pragmatic trials. PLoS Med. 2019, 16, e1002884. [CrossRef] [PubMed]

4. Da Silva, P.E.A.; Palomino, J.C. Molecular basis and mechanisms of drug resistance in Mycobacterium tuberculosis: Classical and new drugs. J. Antimicrob. Chemother. 2011, 66, 1417-1430. [CrossRef]

5. Holmes, K.K.; Bertozzi, S.; Bloom, B.R.; Jha, P. Major Infectious Diseases; The World Bank: Wahington DC, USA, 2017.

6. Migliori, G.B.; Thong, P.M.; Akkerman, O.; Alffenaar, J.-W.; Álvarez-Navascués, F.; Assao-Neino, M.M.; Bernard, P.V.; Biala, J.S.; Blanc, F.-X.; Bogorodskaya, E.M. Worldwide effects of coronavirus disease pandemic on tuberculosis services, January-April 2020. Emerg. Infect. Dis. 2020, 26, 2709. [CrossRef] [PubMed]

7. McQuaid, C.F.; McCreesh, N.; Read, J.M.; Sumner, T.; Houben, R.M.; White, R.G.; Harris, R.C.; Group, C.C.-W. The potential impact of COVID-19-related disruption on tuberculosis burden. Eur. Respir. J. 2020, 56. [CrossRef]

8. Luies, L.; Du Preez, I.; Loots, D.T. The role of metabolomics in tuberculosis treatment research. Biomark. Med. 2017, 11, 1017-1029. [CrossRef]

9. WHO. Consolidated Guidelines on Drug-Resistant Tuberculosis Treatment; World Health Organizationon: Geneva, Switzerland, 2019.

10. Ahmad, N.; Javaid, A.; Sulaiman, S.A.S.; Ming, L.C.; Ahmad, I.; Khan, A.H. Resistance patterns, prevalence, and predictors of fluoroquinolones resistance in multidrug resistant tuberculosis patients. Braz. J. Infect. Dis. 2016, 20, 41-47. [CrossRef]

11. Nguyen, T.V.A.; Anthony, R.M.; Bañuls, A.-L.; Nguyen, T.V.A.; Vu, D.H.; Alffenaar, J.-W.C. Bedaquiline resistance: Its emergence, mechanism, and prevention. Clin. Infect. Dis. 2018, 66, 1625-1630. [CrossRef]

12. Polsfuss, S.; Hofmann-Thiel, S.; Merker, M.; Krieger, D.; Niemann, S.; Rüssmann, H.; Schönfeld, N.; Hoffmann, H.; Kranzer, K. Emergence of low-level delamanid and bedaquiline resistance during extremely drug-resistant tuberculosis treatment. Clin. Infect. Dis. 2019, 69, 1229-1231. [CrossRef]

13. Adeniji, A.A.; Knoll, K.E. Potential anti-TB investigational compounds and drugs with repurposing potential in TB therapy: A conspectus. Appl. Microbiol. Biotechnol. 2020, 104, 5633-5662. [CrossRef]

14. Brown, D. Antibiotic resistance breakers: Can repurposed drugs fill the antibiotic discovery void? Nat. Rev. Drug Discov. 2015, 14, 821-832. [CrossRef] [PubMed] 
15. Pranger, A.; Van Der Werf, T.; Kosterink, J.; Alffenaar, J. The role of fluoroquinolones in the treatment of tuberculosis in 2019. Drugs 2019, 79, 161-171. [CrossRef]

16. Domagala, J.M. Structure-activity and structure-side-effect relationships for the quinolone antibacterials. J. Antimicrob. Chemother. 1994, 33, 685-706. [CrossRef] [PubMed]

17. Berning, S.E. The role of fluoroquinolones in tuberculosis today. Drugs 2001, 61, 9-18. [CrossRef] [PubMed]

18. O'Sullivan, D.M.; Hinds, J.; Butcher, P.D.; Gillespie, S.H.; McHugh, T.D. Mycobacterium tuberculosis DNA repair in response to subinhibitory concentrations of ciprofloxacin. J. Antimicrob. Chemother. 2008, 62, 1199-1202. [CrossRef] [PubMed]

19. Jabeen, K.; Shakoor, S.; Hasan, R. Fluoroquinolone-resistant tuberculosis: Implications in settings with weak healthcare systems. Int. J. Infect. Dis. 2015, 32, 118-123. [CrossRef]

20. Chen, T.-C.; Lu, P.-L.; Lin, C.-Y.; Lin, W.-R.; Chen, Y.-H. Fluoroquinolones are associated with delayed treatment and resistance in tuberculosis: A systematic review and meta-analysis. Int. J. Infect. Dis. 2011, 15, e211-e216. [CrossRef]

21. Raman, K.; Rajagopalan, P.; Chandra, N. Flux balance analysis of mycolic acid pathway: Targets for anti-tubercular drugs. PLoS Comput. Biol. 2005, 1, e46. [CrossRef]

22. Drlica, K.; Zhao, X. DNA gyrase, topoisomerase IV, and the 4-quinolones. Microbiol. Mol. Biol. Rev. 1997, 61, 377-392. [CrossRef]

23. Blondeau, J.M. Fluoroquinolones: Mechanism of action, classification, and development of resistance. Surv. Ophthalmol. 2004, 49, S73-S78. [CrossRef] [PubMed]

24. Zawadzki, P.; Stracy, M.; Ginda, K.; Zawadzka, K.; Lesterlin, C.; Kapanidis, A.N.; Sherratt, D.J. The localization and action of topoisomerase IV in Escherichia coli chromosome segregation is coordinated by the SMC complex, MukBEF. Cell Rep. 2015, 13, 2587-2596. [CrossRef]

25. Walker, R.C. The fluoroquinolones. Mayo Clin. Proc. 1999, 1030-1037. [CrossRef]

26. Collin, F.; Karkare, S.; Maxwell, A. Exploiting bacterial DNA gyrase as a drug target: Current state and perspectives. Appl. Microbiol. Biotechnol. 2011, 92, 479-497. [CrossRef] [PubMed]

27. Chatterji, M.; Unniraman, S.; Mahadevan, S.; Nagaraja, V. Effect of different classes of inhibitors on DNA gyrase from Mycobacterium smegmatis. J. Antimicrob. Chemother. 2001, 48, 479-485. [CrossRef]

28. Zhanel, G.G.; Ennis, K.; Vercaigne, L.; Walkty, A.; Gin, A.S.; Embil, J.; Smith, H.; Hoban, D.J. A critical review of the fluoroquinolones. Drugs 2002, 62, 13-59. [CrossRef]

29. Aldred, K.J.; Blower, T.R.; Kerns, R.J.; Berger, J.M.; Osheroff, N. Fluoroquinolone interactions with Mycobacterium tuberculosis gyrase: Enhancing drug activity against wild-type and resistant gyrase. Proc. Natl. Acad. Sci. USA 2016, 113, E839-E846. [CrossRef]

30. Cheng, G.; Hao, H.; Dai, M.; Liu, Z.; Yuan, Z. Antibacterial action of quinolones: From target to network. Eur. J. Med. Chem. 2013, 66, 555-562. [CrossRef]

31. Bush, N.G.; Diez-Santos, I.; Abbott, L.R.; Maxwell, A. Quinolones: Mechanism, Lethality and Their Contributions to Antibiotic Resistance. Molecules 2020, 25. [CrossRef]

32. Pham, T.D.M.; Ziora, Z.M.; Blaskovich, M.A.T. Quinolone antibiotics. Medchemcomm 2019, 10, 1719-1739. [CrossRef]

33. Jarlier, V.; Nikaido, H. Mycobacterial cell wall: Structure and role in natural resistance to antibiotics. FEMS Microbiol. Lett. 1994, 123, 11-18. [CrossRef]

34. Arjomandzadegan, M.; Titov, L.; Farnia, P.; Owlia, P.; Ranjbar, R.; Sheikholeslami, F.; Surkova, L. Molecular detection of fluoroquinolone resistance-associated gyrA mutations in ofloxacin-resistant clinical isolates of Mycobacterium tuberculosis from Iran and Belarus. Int. J. Mycobacteriology 2016, 5, 299-305. [CrossRef] [PubMed]

35. Angala, S.K.; Belardinelli, J.M.; Huc-Claustre, E.; Wheat, W.H.; Jackson, M. The cell envelope glycoconjugates of Mycobacterium tuberculosis. Crit. Rev. Biochem. Mol. Biol. 2014, 49, 361-399. [CrossRef]

36. Fresta, M.; Guccione, S.; Beccari, A.R.; Furneri, P.M.; Puglisi, G. Combining molecular modeling with experimental methodologies: Mechanism of membrane permeation and accumulation of ofloxacin. Bioorganic Med. Chem. 2002, 10, 3871-3889. [CrossRef]

37. Disratthakit, A.; Prammananan, T.; Tribuddharat, C.; Thaipisuttikul, I.; Doi, N.; Leechawengwongs, M.; Chaiprasert, A. Role of gyrB Mutations in Pre-extensively and Extensively Drug-Resistant Tuberculosis in Thai Clinical Isolates. Antimicrob. Agents Chemother. 2016, 60, 5189-5197. [CrossRef]

38. Blower, T.R.; Williamson, B.H.; Kerns, R.J.; Berger, J.M. Crystal structure and stability of gyrase-fluoroquinolone cleaved complexes from Mycobacterium tuberculosis. Proc. Natl. Acad. Sci. USA 2016, 113, 1706-1713. [CrossRef] [PubMed]

39. Chen, J.; Chen, Z.; Li, Y.; Xia, W.; Chen, X.; Chen, T.; Zhou, L.; Xu, B.; Xu, S. Characterization of gyrA and gyrB mutations and fluoroquinolone resistance in Mycobacterium tuberculosis clinical isolates from Hubei Province, China. Braz. J. Infect. Dis. 2012, 16, 136-141. [PubMed]

40. Aldred, K.J.; Kerns, R.J.; Osheroff, N. Mechanism of quinolone action and resistance. Biochemistry 2014, 53, 1565-1574. [CrossRef]

41. Rossi, E.D.; Aínsa, J.A.; Riccardi, G. Role of mycobacterial efflux transporters in drug resistance: An unresolved question. FEMS Microbiol. Rev. 2006, 30, 36-52. [CrossRef]

42. Radhakrishnan, A.; Kumar, N.; Wright, C.C.; Chou, T.-H.; Tringides, M.L.; Bolla, J.R.; Lei, H.-T.; Rajashankar, K.R.; $\mathrm{Su}$, C.-C.; Purdy, G.E. Crystal structure of the transcriptional regulator Rv0678 of Mycobacterium tuberculosis. J. Biol. Chem. 2014, 289, 16526-16540. [CrossRef]

43. Redgrave, L.S.; Sutton, S.B.; Webber, M.A.; Piddock, L.J. Fluoroquinolone resistance: Mechanisms, impact on bacteria, and role in evolutionary success. Trends Microbiol. 2014, 22, 438-445. [CrossRef] [PubMed] 
44. Montero, C.; Mateu, G.; Rodriguez, R.; Takiff, H. Intrinsic resistance of Mycobacterium smegmatis to fluoroquinolones may be influenced by new pentapeptide protein MfpA. Antimicrob. Agents Chemother. 2001, 45, 3387-3392. [CrossRef] [PubMed]

45. Daisy, P.; Vijayalakshmi, P.; Selvaraj, C.; Singh, S.; Saipriya, K. Targeting multidrug resistant Mycobacterium tuberculosis HtrA2 with identical chemical entities of fluoroquinolones. Indian J. Pharm. Sci. 2012, 74, 217. [CrossRef] [PubMed]

46. Palomino, J.C.; Martin, A. Drug resistance mechanisms in Mycobacterium tuberculosis. Antibiotics 2014, 3, 317-340. [CrossRef]

47. Verma, I.; Rohilla, A.; Khuller, G.K. Alterations in macromolecular composition and cell wall integrity by ciprofloxacin in Mycobacterium smegmatis. Lett. App. Microbiol. 1999, 29, 113-117. [CrossRef] [PubMed]

48. Halouska, S.; Fenton, R.J.; Barletta, R.G.; Powers, R. Predicting the in vivo mechanism of action for drug leads using NMR metabolomics. ACS Chem. Biol. 2012, 7, 166-171. [CrossRef]

49. Ginsburg, A.S.; Grosset, J.H.; Bishai, W.R. Fluoroquinolones, tuberculosis, and resistance. Lancet Infect. Dis. 2003, 3, 432-442. [CrossRef]

50. Ross, A.G.; Benton, B.M.; Chin, D.; De Pascale, G.; Fuller, J.; Leeds, J.A.; Reck, F.; Richie, D.L.; Vo, J.; LaMarche, M.J. Synthesis of ciprofloxacin dimers for evaluation of bacterial permeability in atypical chemical space. Bioorg. Med. Chem. Lett. 2015, 25, 3468-3475. [CrossRef] [PubMed]

51. Tyagi, P.; Dharmaraja, A.T.; Bhaskar, A.; Chakrapani, H.; Singh, A. Mycobacterium tuberculosis has diminished capacity to counteract redox stress induced by elevated levels of endogenous superoxide. Free Radic. Biol. Med. 2015, 84, 344-354. [CrossRef]

52. Podlesek, Z.; Zgur Bertok, D. The DNA Damage Inducible SOS Response Is a Key Player in the Generation of Bacterial Persister Cells and Population Wide Tolerance. Front. Microbiol. 2020, 11, 1785. [CrossRef]

53. Arbex, M.A.; Varella, M.d.C.L.; Siqueira, H.R.d.; Mello, F.A.F.d. Antituberculosis drugs: Drug interactions, adverse effects, and use in special situations-part 2: Second line drugs. J. Bras. Pneumol. 2010, 36, 641-656. [CrossRef]

54. Gorelik, E.; Masarwa, R.; Perlman, A.; Rotshild, V.; Abbasi, M.; Muszkat, M.; Matok, I. Fluoroquinolones and cardiovascular risk: A systematic review, meta-analysis and network meta-analysis. Drug Saf. 2019, 42, 529-538. [CrossRef] [PubMed]

55. Schloss, M.; Becak, D.; Tosto, S.T.; Velayati, A. A case of Levofloxacin-Induced hepatotoxicity. Am. J. Case Rep. 2018, 19, 272. [CrossRef] [PubMed]

56. Aminimanizani, A.; Beringer, P.; Jelliffe, R. Comparative pharmacokinetics and pharmacodynamics of the newer fluoroquinolone antibacterials. Clin. Pharmacokinet. 2001, 40, 169-187. [CrossRef] [PubMed]

57. Xu, Z.; Zhao, S.J.; Deng, J.L.; Wang, Q.; Lv, Z.S. Ciprofloxacin-Isatin Hybrids and Their Antimycobacterial Activities. J. Heterocyc. Chem. 2019, 56, 319-324. [CrossRef]

58. Ball, P. Ciprofloxacin: An overview of adverse experiences. J. Antimicrob. Chemother. 1986, 18, 187-193. [CrossRef] [PubMed]

59. Barnhill, A.E.; Brewer, M.T.; Carlson, S.A. Adverse effects of antimicrobials via predictable or idiosyncratic inhibition of host mitochondrial components. Antimicrob. Agents Chemother. 2012, 56, 4046-4051. [CrossRef]

60. Hangas, A.; Aasumets, K.; Kekäläinen, N.J.; Paloheinä, M.; Pohjoismäki, J.L.; Gerhold, J.M.; Goffart, S. Ciprofloxacin impairs mitochondrial DNA replication initiation through inhibition of Topoisomerase 2. Nucleic Acids Res. 2018, 46, 9625-9636. [CrossRef]

61. WHO. Critically Important Antimicrobials for Human Medicine, 6th ed.; World Health Organization: Geneva, Switzerland, 2019; Available online: https:/ / creativecommons.org/licenses/by-nc-sa/3.0/igo (accessed on 20 October 2020).

62. Correia, S.; Poeta, P.; Hébraud, M.; Capelo, J.L.; Igrejas, G. Mechanisms of quinolone action and resistance: Where do we stand? J. Med. Microbiol. 2017, 66, 551-559. [CrossRef]

63. Lau, S.K.; Lam, C.-W.; Curreem, S.O.; Lee, K.-C.; Lau, C.C.; Chow, W.-N.; Ngan, A.H.; To, K.K.; Chan, J.F.; Hung, I.F. Identification of specific metabolites in culture supernatant of Mycobacterium tuberculosis using metabolomics: Exploration of potential biomarkers. Emerg. Microbes Infect. 2015, 4, 1-10. [CrossRef]

64. Franzblau, S.G.; Witzig, R.S.; McLaughlin, J.C.; Torres, P.; Madico, G.; Hernandez, A.; Degnan, M.T.; Cook, M.B.; Quenzer, V.K.; Ferguson, R.M. Rapid, low-technology MIC determination with clinical Mycobacterium tuberculosis isolates by using the microplate Alamar Blue assay. J. Clin. Microbiol. 1998, 36, 362-366. [CrossRef] [PubMed]

65. Van Breda, S.V.; Buys, A.; Apostolides, Z.; Nardell, E.A.; Stoltz, A.C. The antimicrobial effect of colistin methanesulfonate on Mycobacterium tuberculosis in vitro. Tuberculosis 2015, 95, 440-446. [CrossRef] [PubMed]

66. Palomino, J.; Portaels, F. Effects of decontamination methods and culture conditions on viability of Mycobacterium ulcerans in the BACTEC system. J. Clin. Microbiol. 1998, 36, 402-408. [CrossRef] [PubMed]

67. Beukes, D.; du Preez, I.; Loots, D.T. Total Metabolome Extraction from Mycobacterial Cells for GC-MS Metabolomics Analysis. Methods Mol. Biol. 2019, 1859, 121-131. [CrossRef]

68. Gromski, P.S.; Xu, Y.; Kotze, H.L.; Correa, E.; Ellis, D.I.; Armitage, E.G.; Turner, M.L.; Goodacre, R. Influence of missing values substitutes on multivariate analysis of metabolomics data. Metabolites 2014, 4, 433-452. [CrossRef] [PubMed]

69. Wei, R.; Wang, J.; Su, M.; Jia, E.; Chen, S.; Chen, T.; Ni, Y. Missing value imputation approach for mass spectrometry-based metabolomics data. Sci. Rep. 2018, 8, 1-10. [CrossRef]

70. Shen, X.; Zhu, Z.-J. MetFlow: An interactive and integrated workflow for metabolomics data cleaning and differential metabolite discovery. Bioinformatics 2019, 35, 2870-2872. [CrossRef]

71. Xia, J.; Wishart, D.S. Web-based inference of biological patterns, functions and pathways from metabolomic data using MetaboAnalyst. Nat. Protoc. 2011, 6, 743-760. [CrossRef]

72. Meissner-Roloff, R.J.; Koekemoer, G.; Warren, R.M. A metabolomics investigation of a hyper-and hypo-virulent phenotype of Beijing lineage M. tuberculosis. Metabolomics 2012, 8, 1194-1203. [CrossRef] 
73. Sullivan, G.M.; Feinn, R. Using effect size—or why the P value is not enough. J. Grad. Med. Educ. 2012, 4, 279. [CrossRef]

74. Cho, H.-W.; Kim, S.B.; Jeong, M.K.; Park, Y.; Miller, N.; Ziegler, T.; Jones, D. Discovery of metabolite features for the modelling and analysis of high-resolution NMR spectra. Int. J. Data Min. Bioinform. 2008, 2, 176-192. [CrossRef] [PubMed]

75. Byliński, H.; Dymerski, T.; Gębicki, J.; Namieśnik, J. Complementary use of GCxGC-TOF-MS and statistics for differentiation of variety in biosolid samples. Mon. Für Chem. Chem. Mon. 2018, 149, 1587-1594. [CrossRef] [PubMed]

76. Coe, R. It's the Effect Size, Stupid: What Effect Size is and Why it is Important; Education-Online: Exeter, UK, 2002.

77. Vijay, S.; Vinh, D.N.; Hai, H.T.; Ha, V.T.N.; Dung, V.T.M.; Dinh, T.D.; Nhung, H.N.; Tram, T.T.B.; Aldridge, B.B.; Hanh, N.T.; et al. Influence of Stress and Antibiotic Resistance on Cell-Length Distribution in Mycobacterium tuberculosis Clinical Isolates. Front. Microbiol. 2017, 8, 2296. [CrossRef] [PubMed]

78. Chatterjee, D.; Bozic, C.M.; McNeil, M.; Brennan, P.J. Structural features of the arabinan component of the lipoarabinomannan of Mycobacterium tuberculosis. J. Biol. Chem. 1991, 266, 9652-9660. [CrossRef]

79. Jankute, M.; Cox, J.A.; Harrison, J.; Besra, G.S. Assembly of the Mycobacterial Cell Wall. Annu Rev. Microbiol 2015, 69, 405-423. [CrossRef]

80. Chiaradia, L.; Lefebvre, C.; Parra, J.; Marcoux, J.; Burlet-Schiltz, O.; Etienne, G.; Tropis, M.; Daffé, M. Dissecting the mycobacterial cell envelope and defining the composition of the native mycomembrane. Sci. Rep. 2017, 7, 1-12. [CrossRef]

81. Abrahams, K.A.; Besra, G.S. Mycobacterial cell wall biosynthesis: A multifaceted antibiotic target. Parasitology 2018, 145, 116-133. [CrossRef]

82. Black, P.N.; DiRusso, C.C. Transmembrane movement of exogenous long-chain fatty acids: Proteins, enzymes, and vectorial esterification. Microbiol. Mol. Biol. Rev. 2003, 67, 454-472. [CrossRef]

83. Santangelo, M.P.; Heuberger, A.; Blanco, F.; Forrellad, M.; Taibo, C.; Klepp, L.; García, J.S.; Nikel, P.I.; Jackson, M.; Bigi, F. Metabolic profile of Mycobacterium smegmatis reveals Mce4 proteins are relevant for cell wall lipid homeostasis. Metabolomics 2016, 12, 97. [CrossRef]

84. Nigou, J.; Gilleron, M.; Puzo, G. Lipoarabinomannans: From structure to biosynthesis. Biochimie 2003, 85, 153-166. [CrossRef]

85. Škovierová, H.; Larrouy-Maumus, G.; Zhang, J.; Kaur, D.; Barilone, N.; Korduláková, J.; Gilleron, M.; Guadagnini, S.; Belanová, M.; Prevost, M.-C. AftD, a novel essential arabinofuranosyltransferase from mycobacteria. Glycobiology 2009, 19, 1235-1247. [CrossRef] [PubMed]

86. Vilchèze, C.; Jacobs, W.R. Isolation and analysis of Mycobacterium tuberculosis mycolic acids. Curr. Protoc. Microbiol. 2007, 5, 10A.13.1-10A.12.11. [CrossRef] [PubMed]

87. Fulco, A.J.; Bloch, K. Cofactor requirements for the formation of $\Delta 9$-unsaturated fatty acids in Mycobacterium phlei. J. Biol. Chem. 1964, 239, 993-997. [CrossRef]

88. Fulco, A.J.; Levy, R.; Bloch, K. The Biosynthesis of $\Delta 9$-and $\Delta 5$-Monosaturated Fatty Acids by Bacteria. J. Biol. Chem. 1964, 239, 998-1003. [CrossRef]

89. Delmar, J.A.; Chou, T.H.; Wright, C.C.; Licon, M.H.; Doh, J.K.; Radhakrishnan, A.; Kumar, N.; Lei, H.T.; Bolla, J.R.; Rajashankar, K.R.; et al. Structural Basis for the Regulation of the MmpL Transporters of Mycobacterium tuberculosis. J. Biol. Chem. 2015, 290, 28559-28574. [CrossRef] [PubMed]

90. Melly, G.; Purdy, G.E. MmpL Proteins in Physiology and Pathogenesis of M. tuberculosis. Microorganisms 2019, 7, 70. [CrossRef]

91. Rhee, K.Y.; de Carvalho, L.P.; Bryk, R.; Ehrt, S.; Marrero, J.; Park, S.W.; Schnappinger, D.; Venugopal, A.; Nathan, C. Central carbon metabolism in Mycobacterium tuberculosis: An unexpected frontier. Trends Microbiol. 2011, 19, 307-314. [CrossRef] [PubMed]

92. Loots, D.T. An Altered Mycobacterium tuberculosis Metabolome Induced by katG Mutations Resulting in Isoniazid Resistance. Antimicrob. Agents Chemother. 2014, 58, 2144-2149. [CrossRef]

93. Zhao, J.; Han, M.-L.; Zhu, Y.; Lin, Y.-W.; Wang, Y.-W.; Lu, J.; Hu, Y.; Zhou, Q.T.; Velkov, T.; Li, J. Comparative metabolomics reveals key pathways associated with the synergistic activity of polymyxin $\mathrm{B}$ and rifampicin combination against multidrug-resistant Acinetobacter baumannii. Biochem. Pharmacol. 2021, 184, 114400. [CrossRef]

94. Rosen, B.C.; Dillon, N.A.; Peterson, N.D.; Minato, Y.; Baughn, A.D. Long-Chain Fatty Acyl Coenzyme A Ligase FadD2 Mediates Intrinsic Pyrazinamide Resistance in Mycobacterium tuberculosis. Antimicrob. Agents Chemother. 2017, 61. [CrossRef]

95. Baptista, R.; Fazakerley, D.M.; Beckmann, M.; Baillie, L.; Mur, L.A. Untargeted metabolomics reveals a new mode of action of pretomanid (PA-824). Sci. Rep. 2018, 8, 1-7. [CrossRef]

96. Xiang, X.; Gong, Z.; Deng, W.; Sun, Q.; Xie, J. Mycobacterial ethambutol responsive genes and implications in antibiotics resistance. J. Drug Target. 2021, 29, 284-293. [CrossRef] [PubMed]

97. Bothra, A.; Arumugam, P.; Panchal, V.; Menon, D.; Srivastava, S.; Shankaran, D.; Nandy, A.; Jaisinghani, N.; Singh, A.; Gokhale, R.S.; et al. Phospholipid homeostasis, membrane tenacity and survival of Mtb in lipid rich conditions is determined by MmpL11 function. Sci. Rep. 2018, 8, 8317. [CrossRef] [PubMed]

98. Zerbini, E.; Cardoso, M.; Sequeira, M.; Taher, H.; Santi, N.; Larpin, D.; Latini, O.; Tonarelli, G. Characterization of fatty acids and mycolic acid degradation products in mycobacterial species of major incidence in Argentina. Rev. Argent. De Microbiol. 1997, 29, 184-194.

99. Crellin, P.K.; Brammananth, R.; Coppel, R.L. Decaprenylphosphoryl-beta-D-ribose 2'-epimerase, the target of benzothiazinones and dinitrobenzamides, is an essential enzyme in Mycobacterium smegmatis. PLoS ONE 2011, 6, e16869. [CrossRef] [PubMed]

100. Kumar, R.; Sanyal, S. Mycobacterium tuberculosis: Dormancy, Persistence and Survival in the Light of Protein Synthesis. In Understanding Tuberculosis_Deciphering the Secret Life of the Bacilli; ResearchGate: Stockholm, Sweden, 2012. 
101. Kumar, A.; Farhana, A.; Guidry, L.; Saini, V.; Hondalus, M.; Steyn, A.J. Redox homeostasis in mycobacteria: The key to tuberculosis control? Expert Rev. Mol. Med. 2011, 13, e39. [CrossRef]

102. Erental, A.; Kalderon, Z.; Saada, A.; Smith, Y.; Engelberg-Kulka, H. Apoptosis-like death, an extreme SOS response in Escherichia coli. mBio 2014, 5, e01426-01414. [CrossRef]

103. Horecker, B.L. The pentose phosphate pathway. J. Biol. Chem. 2002, 277, 47965-47971. [CrossRef]

104. Lucarelli, A.P.; Buroni, S.; Pasca, M.R.; Rizzi, M.; Cavagnino, A.; Valentini, G.; Riccardi, G.; Chiarelli, L.R. Mycobacterium tuberculosis phosphoribosylpyrophosphate synthetase: Biochemical features of a crucial enzyme for mycobacterial cell wall biosynthesis. PLoS ONE 2010, 5, e15494. [CrossRef]

105. Larrouy-Maumus, G.; Marino, L.B.; Madduri, A.V.; Ragan, T.J.; Hunt, D.M.; Bassano, L.; Gutierrez, M.G.; Moody, D.B.; Pavan, F.R.; de Carvalho, L.P. Cell-Envelope Remodeling as a Determinant of Phenotypic Antibacterial Tolerance in Mycobacterium tuberculosis. ACS Infect. Dis. 2016, 2, 352-360. [CrossRef]

106. Kampranis, S.C.; Maxwell, A. The DNA gyrase-quinolone complex. ATP hydrolysis and the mechanism of DNA cleavage. J. Biol. Chem. 1998, 273, 22615-22626. [CrossRef]

107. Villela, A.D.; Sanchez-Quitian, Z.A.; Ducati, R.G.; Santos, D.S.; Basso, L.A. Pyrimidine salvage pathway in Mycobacterium tuberculosis. Curr. Med. Chem. 2011, 18, 1286-1298. [CrossRef]

108. Maitra, A.; Munshi, T.; Healy, J.; Martin, L.T.; Vollmer, W.; Keep, N.H.; Bhakta, S. Cell wall peptidoglycan in Mycobacterium tuberculosis: An Achilles' heel for the TB-causing pathogen. FEMS Microbiol. Rev. 2019, 43, 548-575. [CrossRef] [PubMed]

109. Miggiano, R.; Morrone, C.; Rossi, F.; Rizzi, M. Targeting Genome Integrity in Mycobacterium Tuberculosis: From Nucleotide Synthesis to DNA Replication and Repair. Molecules 2020, 25, 1205. [CrossRef]

110. Haites, R.E.; Morita, Y.S.; McConville, M.J.; Billman-Jacobe, H. Function of phosphatidylinositol in mycobacteria. J. Biol. Chem. 2005, 280, 10981-10987. [CrossRef] [PubMed]

111. Heijenoort, J.v. Formation of the glycan chains in the synthesis of bacterial peptidoglycan. Glycobiology 2001, 11, 25R-36R. [CrossRef] [PubMed]

112. Titgemeyer, F.; Amon, J.; Parche, S.; Mahfoud, M.; Bail, J.; Schlicht, M.; Rehm, N.; Hillmann, D.; Stephan, J.; Walter, B.; et al. A genomic view of sugar transport in Mycobacterium smegmatis and Mycobacterium tuberculosis. J. Bacteriol. 2007, 189, 5903-5915. [CrossRef] [PubMed]

113. Alderwick, L.J.; Lloyd, G.S.; Lloyd, A.J.; Lovering, A.L.; Eggeling, L.; Besra, G.S. Biochemical characterization of the Mycobacterium tuberculosis phosphoribosyl-1-pyrophosphate synthetase. Glycobiology 2011, 21, 410-425. [CrossRef] [PubMed]

114. Klutts, J.S.; Hatanaka, K.; Pan, Y.T.; Elbein, A.D. Biosynthesis of d-arabinose in Mycobacterium smegmatis: Specific labeling from d-glucose. Arch. Biochem. Biophys. 2002, 398, 229-239. [CrossRef]

115. Sheppard, K.; Yuan, J.; Hohn, M.J.; Jester, B.; Devine, K.M.; Soll, D. From one amino acid to another: tRNA-dependent amino acid biosynthesis. Nucleic Acids Res. 2008, 36, 1813-1825. [CrossRef]

116. Kudo, F.; Miyanaga, A.; Eguchi, T. Biosynthesis of natural products containing beta-amino acids. Nat. Prod. Rep. 2014, 31, 1056-1073. [CrossRef] [PubMed]

117. Rieck, B.; Degiacomi, G.; Zimmermann, M.; Cascioferro, A.; Boldrin, F.; Lazar-Adler, N.R.; Bottrill, A.R.; le Chevalier, F.; Frigui, W.; Bellinzoni, M.; et al. PknG senses amino acid availability to control metabolism and virulence of Mycobacterium tuberculosis. PLoS Pathog. 2017, 13, e1006399. [CrossRef] [PubMed]

118. Hasenoehrl, E.J.; Rae Sajorda, D.; Berney-Meyer, L.; Johnson, S.; Tufariello, J.M.; Fuhrer, T.; Cook, G.M.; Jacobs, W.R., Jr.; Berney, M. Derailing the aspartate pathway of Mycobacterium tuberculosis to eradicate persistent infection. Nat. Commun. 2019, $10,4215$. [CrossRef] [PubMed]

119. Rizvi, A.; Yousf, S.; Balakrishnan, K.; Dubey, H.K.; Mande, S.C.; Chugh, J.; Banerjee, S. Metabolomics Studies to Decipher Stress Responses in Mycobacterium smegmatis Point to a Putative Pathway of Methylated Amine Biosynthesis. J. Bacteriol. $2019,201$. [CrossRef]

120. Genschel, U. Coenzyme A biosynthesis: Reconstruction of the pathway in archaea and an evolutionary scenario based on comparative genomics. Mol. Biol. Evol. 2004, 21, 1242-1251. [CrossRef] [PubMed]

121. Leonardi, R.; Jackowski, S. Biosynthesis of pantothenic acid and coenzyme A. Ecosal Plus 2007, 2. [CrossRef]

122. Daniel, J.; Sirakova, T.; Kolattukudy, P. An acyl-CoA synthetase in Mycobacterium tuberculosis involved in triacylglycerol accumulation during dormancy. PLoS ONE 2014, 9, e114877. [CrossRef] [PubMed]

123. Massey, L.K.; Sokatch, J.R.; Conrad, R.S. Branched-chain amino acid catabolism in bacteria. Bacteriol. Rev. 1976, 40, 42. [CrossRef]

124. Surger, M.J.; Angelov, A.; Stier, P.; Ubelacker, M.; Liebl, W. Impact of Branched-Chain Amino Acid Catabolism on Fatty Acid and Alkene Biosynthesis in Micrococcus luteus. Front. Microbiol. 2018, 9, 374. [CrossRef]

125. Zhao, H.; Roistacher, D.M.; Helmann, J.D. Aspartate deficiency limits peptidoglycan synthesis and sensitizes cells to antibiotics targeting cell wall synthesis in Bacillus subtilis. Mol. Microbiol. 2018, 109, 826-844. [CrossRef]

126. Rodionova, I.A.; Schuster, B.M.; Guinn, K.M.; Sorci, L.; Scott, D.A.; Li, X.; Kheterpal, I.; Shoen, C.; Cynamon, M.; Locher, C. Metabolic and bactericidal effects of targeted suppression of NadD and NadE enzymes in mycobacteria. MBio 2014, 5. [CrossRef] [PubMed]

127. Ramakrishnan, T.; Murthy, P.S.; Gobinathan, K.P. Intermediary Metabolism of Mycobacteria. Bacteriol. Rev. 1972, 36, 65-108. [CrossRef] [PubMed] 
128. Heath, R.J.; Rubin, J.R.; Holland, D.R.; Zhang, E.; Snow, M.E.; Rock, C.O. Mechanism of triclosan inhibition of bacterial fatty acid synthesis. J. Biol. Chem. 1999, 274, 11110-11114. [CrossRef]

129. Martin, J.L.; McMillan, F.M. SAM (dependent) I AM: The S-adenosylmethionine-dependent methyltransferase fold. Curr. Opin. Struct. Biol. 2002, 12, 783-793. [CrossRef]

130. Crick, D.C.; Mahapatra, S.; Brennan, P.J. Biosynthesis of the arabinogalactan-peptidoglycan complex of Mycobacterium tuberculosis. Glycobiology 2001, 11, 107R-118R. [CrossRef]

131. Agapova, A.; Serafini, A.; Petridis, M.; Hunt, D.M.; Garza-Garcia, A.; Sohaskey, C.D.; de Carvalho, L.P.S. Flexible nitrogen utilisation by the metabolic generalist pathogen Mycobacterium tuberculosis. Elife 2019, 8. [CrossRef]

132. Iacobino, A.; Piccaro, G.; Pardini, M.; Fattorini, L.; Giannoni, F. Moxifloxacin Activates the SOS Response in Mycobacterium tuberculosis in a Dose- and Time-Dependent Manner. Microorganisms 2021, 9, 255. [CrossRef]

133. Petridis, M.; Vickers, C.; Robson, J.; McKenzie, J.L.; Bereza, M.; Sharrock, A.; Aung, H.L.; Arcus, V.L.; Cook, G.M. Structure and Function of AmtR in Mycobacterium smegmatis: Implications for Post-Transcriptional Regulation of Urea Metabolism through a Small Antisense RNA. J. Mol. Biol. 2016, 428, 4315-4329. [CrossRef]

134. Gouzy, A.; Poquet, Y.; Neyrolles, O. Nitrogen metabolism in Mycobacterium tuberculosis physiology and virulence. Nat. Rev. Microbiol. 2014, 12, 729-737. [CrossRef]

135. Stallings, C.L.; Stephanou, N.C.; Chu, L.; Hochschild, A.; Nickels, B.E.; Glickman, M.S. CarD is an essential regulator of rRNA transcription required for Mycobacterium tuberculosis persistence. Cell 2009, 138, 146-159. [CrossRef]

136. Khan, M.T.; Rehaman, A.U.; Junaid, M.; Malik, S.I.; Wei, D.Q. Insight into novel clinical mutants of RpsA-S324F, E325K, and G341R of Mycobacterium tuberculosis associated with pyrazinamide resistance. Comput. Struct. Biotechnol. J. 2018, 16, 379-387. [CrossRef] [PubMed]

137. Patil, P.S.; Kasare, S.L.; Haval, N.B.; Khedkar, V.M.; Dixit, P.P.; Rekha, E.M.; Sriram, D.; Haval, K.P. Novel isoniazid embedded triazole derivatives: Synthesis, antitubercular and antimicrobial activity evaluation. Bioorg. Med. Chem. Lett. 2020, $30,127434$. [CrossRef] [PubMed]

138. Burke, C.; Jankute, M.; Moynihan, P.; Gonzalez Del Rio, R.; Li, X.; Esquivias, J.; Lelievre, J.; Cox, J.A.G.; Sacchettini, J.; Besra, G.S. Development of a novel secondary phenotypic screen to identify hits within the mycobacterial protein synthesis pipeline. FASEB Bioadv. 2020, 2, 600-612. [CrossRef]

139. Yancey, P.H. Water Stress, Osmolytes and Proteins. Amer. Zool. 2001, 41, 699-709. [CrossRef]

140. Majumdar, R.; Barchi, B.; Turlapati, S.A.; Gagne, M.; Minocha, R.; Long, S.; Minocha, S.C. Glutamate, Ornithine, Arginine, Proline, and Polyamine Metabolic Interactions: The Pathway Is Regulated at the Post-Transcriptional Level. Front. Plant. Sci $2016,7,78$. [CrossRef] [PubMed]

141. Jain, A.; Tyagi, A.K. Role of polyamines in the synthesis of RNA in mycobacteria. Mol. Cell Biochem. 1987, 78, 3-8. [CrossRef] [PubMed]

142. Sarathy, J.P.; Lee, E.; Dartois, V. Polyamines inhibit porin-mediated fluoroquinolone uptake in mycobacteria. PLoS ONE 2013, 8, e65806. [CrossRef]

143. Ortalo-Magne, A.; Lemassu, A.; Laneelle, M.-A.; Bardou, F.; Silve, G.; Gounon, P.; Marchal, G.; Daffé, M. Identification of the surface-exposed lipids on the cell envelopes of Mycobacterium tuberculosis and other mycobacterial species. J. Bacteriol. 1996, 178, 456-461. [CrossRef]

144. Singh, A.; Crossman, D.K.; Mai, D.; Guidry, L.; Voskuil, M.I.; Renfrow, M.B.; Steyn, A.J. Mycobacterium tuberculosis WhiB3 maintains redox homeostasis by regulating virulence lipid anabolism to modulate macrophage response. PLoS Pathog. 2009, 5, e1000545. [CrossRef]

145. Muñoz-Elías, E.J.; Upton, A.M.; Cherian, J.; McKinney, J.D. Role of the methylcitrate cycle in Mycobacterium tuberculosis metabolism, intracellular growth, and virulence. Mol. Microbiol. 2006, 60, 1109-1122. [CrossRef]

146. Daniel, J.; Deb, C.; Dubey, V.S.; Sirakova, T.D.; Abomoelak, B.; Morbidoni, H.R.; Kolattukudy, P.E. Induction of a novel class of diacylglycerol acyltransferases and triacylglycerol accumulation in Mycobacterium tuberculosis as it goes into a dormancy-like state in culture. J. Bacteriol. 2004, 186, 5017-5030. [CrossRef]

147. Crellin, P.K.; Luo, C.-Y.; Morita, Y.S. Metabolism of Plasma Membrane Lipids in Mycobacteria and Corynebacteria. In Lipid Metabolism; IntechOpen: London, UK, 2013.

148. Deb, C.; Daniel, J.; Sirakova, T.D.; Abomoelak, B.; Dubey, V.S.; Kolattukudy, P.E. A novel lipase belonging to the hormone-sensitive lipase family induced under starvation to utilize stored triacylglycerol in Mycobacterium tuberculosis. J. Biol. Chem. 2006, 281, 3866-3875. [CrossRef]

149. Barksdale, L.; Kim, K.-S. Mycobacterium. Bacteriol. Rev. 1977, 41, 217. [CrossRef] [PubMed]

150. Athenstaedt, K.; Daum, G. Phosphatidic acid, a key intermediate in lipid metabolism. Eur. J. Biochem. 1999, 266, 1-16. [CrossRef] [PubMed]

151. Rottig, A.; Steinbuchel, A. Acyltransferases in bacteria. Microbiol. Mol. Biol. Rev. 2013, 77, 277-321. [CrossRef] [PubMed]

152. Aschauer, P.; Zimmermann, R.; Breinbauer, R.; Pavkov-Keller, T.; Oberer, M. The crystal structure of monoacylglycerol lipase from M. tuberculosis reveals the basis for specific inhibition. Sci. Rep. 2018, 8, 8948. [CrossRef] [PubMed]

153. Clarke, O.B.; Tomasek, D.; Jorge, C.D.; Dufrisne, M.B.; Kim, M.; Banerjee, S.; Rajashankar, K.R.; Shapiro, L.; Hendrickson, W.A.; Santos, H.; et al. Structural basis for phosphatidylinositol-phosphate biosynthesis. Nat. Commun. 2015, 6, 8505. [CrossRef] [PubMed] 
154. Salman, M.; Lonsdale, J.T.; Besra, G.S.; Brenna, P.J. Phosphatidylinositol synthesis in mycobacteria. Biochim. Biophys. Acta 1999, 1436, 437-450. [CrossRef]

155. Newton, G.L.; Ta, P.; Bzymek, K.P.; Fahey, R.C. Biochemistry of the initial steps of mycothiol biosynthesis. J. Biol. Chem. 2006, 281, 33910-33920. [CrossRef] [PubMed]

156. Mehaffy, C.; Islam, M.N.; Fitzgerald, B.; Belisle, J.; Prenni, J.; Dobos, K. Biochemical characterization of isoniazid-resistant Mycobacterium tuberculosis: Can the analysis of clonal strains reveal novel targetable pathways? Mol. Cell. Proteom. 2018, $17,1685-1701$.

157. Sun, L.; Zhang, L.; Wang, T.; Jiao, W.; Li, Q.; Yin, Q.; Li, J.; Qi, H.; Xu, F.; Shen, C. Mutations of Mycobacterium tuberculosis induced by anti-tuberculosis treatment result in metabolism changes and elevation of ethambutol resistance. Infect. Genet. Evol. 2019, 72, 151-158. [CrossRef] [PubMed]

158. Khan, M.T.; Khan, A.; Rehman, A.U.; Wang, Y.; Akhtar, K.; Malik, S.I.; Wei, D.Q. Structural and free energy landscape of novel mutations in ribosomal protein S1 (rpsA) associated with pyrazinamide resistance. Sci. Rep. 2019, 9, 7482. [CrossRef]

159. Combrink, M.; du Preez, I. Metabolomics describes previously unknown toxicity mechanisms of isoniazid and rifampicin. Toxicol. Lett. 2020, 322, 104-110. [CrossRef]

160. Qin, T.T.; Kang, H.Q.; Ma, P.; Li, P.P.; Huang, L.Y.; Gu, B. SOS response and its regulation on the fluoroquinolone resistance. Ann. Transl. Med. 2015, 3, 358. [CrossRef] [PubMed]

161. Tian, J.; Bryk, R.J.; Itoh, M.; Suematsu, M.; Nathan, C. Variant tricarboxylic acid cycle in Mycobacterium tuberculosis: Identification of a-ketoglutarate decarboxylase. PNAS 2005, 102, 10670-10675. [CrossRef]

162. Torres-Barceló, C.; Kojadinovic, M.; Moxon, R.; MacLean, R.C. The SOS response increases bacterial fitness, but not evolvability, under a sublethal dose of antibiotic. Proc. R. Soc. B Biol. Sci. 2015, 282, 20150885. [CrossRef] [PubMed] 